\title{
They Will Definitely Need Us, When We Are 64: Old-Age Provision in Germany
}

For the next two decades, Germany will be among the fastest ageing countries in Europe and in the world. This is not so much due to an extraordinary level of, or increase in, life expectancy. In fact, longevity in Germany is currently close to the EU average, and it is expected to go up slightly less than elsewhere in the future (European Commission and EU Economic Policy Committee, 2017, 7). However, following a baby boom that was relatively late and small by international standards, the German total fertility rate fell from 2.5 to under 1.5 between 1965 and 1975 (Statistisches Bundesamt, 2020, 5-7). In West Germany, the rate has fluctuated around 1.4 during the four decades that followed, showing a slight increase only very recently. 1

The fast and strong reduction in the number of births has triggered a long-term shift in the age composition of the population that is still ongoing and, with an eye on oldage provision, will now become acute soon. The German baby boomers will enter retirement by 2030 . During this period, old-age dependency will roughly double that of its 2000 level and, thus far, there are no signs that it will go down again until 2060 (Statistisches Bundesamt, 2019) or even afterwards (Werding and Läpple, 2019). Obviously, this change in demographic fundamentals creates a huge challenge for the German Statutory Pension Scheme which is operated on a pay-as-you-go basis and is still the dominant pillar of the overall system of old-age provision in this country.

Politicians have responded to this challenge through a wave of reforms taken in the early 2000s, which have

(C) The Author(s) 2020. Open Access: This article is distributed under the terms of the Creative Commons Attribution 4.0 International License (https://creativecommons.org/licenses/by/4.0/).

Open Access funding provided by ZBW - Leibniz Information Centre for Economics.

1 Despite the differing political and economic systems, fertility trends in East-Germany were surprisingly similar to those in the West until 1975. Afterwards, the East-German fertility rate was pushed up again (to over 1.8) for a short while by strongly pro-natalist policies, but the effects subsided over the 1980s. During the economic transition, the rate dropped dramatically (to below 0.8) in the early 1990s. Since then, it has converged to the West-German level (Kreyenfeld, 2001).

Martin Werding, Ruhr-University Bochum; and CESifo Research Network, Munich, Germany. rendered the system financially viable until around 2025 . While these reforms took effect, labour market performance has remarkably improved against earlier years and remained almost unaffected by the Great Recession. This has created temptations to partly undo the reforms that are already in place. Some steps in this direction have been made through amendments enacted in recent years. Untimely demands for additional and more farreaching reversals of earlier reforms are now on the table, when plans have to be devised for how to fully adjust the pension system in light of a strong and lasting ageing process.

Currently, a government commission consisting of politicians, social partners and researchers is expected to draft a new series of pension reforms with a time horizon until 2045. After more than a year of internal discussions and only a few weeks before the scheduled release of a final report, it is unclear whether this group will be able to reach any agreements.

\section{Earlier reforms and recent amendments}

Various figures from Deutsche Rentenversicherung (2020) can be used to demonstrate that, for the moment, the budget of the German public pension scheme has a rather favourable stance. In 2019, it spent almost 290 billion euro - close to $9 \%$ of GDP - on old-age, survivor and disability benefits. It holds reserves of 40 billion euro, exceeding the legal ceiling for the eighth year in a row. The contribution rate is currently at $18.6 \%$ of covered wages, down from a peak at $20.3 \%$ reached in 1997-1999. While this situation must be expected to change rather soon, it is the result of a series of major reforms, supported by the effects of a strong labour market performance. The reforms were enacted between 2001 and 2007, based on the recommendations of another government commission.

In 2001, German pension policy abandoned the task of providing for a constant level of benefits that had been pursued - with a few alterations of the precise definition - since the late 1950s. Instead, an ad hoc correction was introduced in the formula for annual benefit upratings which was meant to reduce the net benefit level (compared to current wages of those contributing to the system) in the long run. In 2004, this was replaced by a self-stabilisation mechanism (Börsch-Supan, 2007) by 
which annual benefit up-ratings were inversely linked to changes in the system dependency ratio (number of pensioners per contributors) that was projected to increase continuously in the future, with a strong acceleration between 2020 and 2030. Another important element of the 2001 reform was the introduction of a subsidised scheme for supplementary, private provisions, where active members of the public pension scheme were expected to save up to $4 \%$ of their covered earnings, in order to make up for the gradual decline in the benefit level of the public scheme.

The most controversial issue in these reforms was an increase in the statutory age threshold for drawing full benefits. In 2007, a law was finally made prescribing an increase of this age threshold from 65 to 67 , for women and men alike, which was to become effective between 2012 and 2031. In spite of persistent criticisms, the increase has been phased in as scheduled. Together, these reforms brought enormous improvements regarding the prospects of ever-rising contribution rates (Werding, 2007). The unexpected rise in employment that followed due to (among other things) strongly increasing participation rates of older workers (Werding, 2016, R14-R15) even led to temporary reductions in the contribution rate. Over time, this resulted in discussions about the ongoing decline in the benefit level which, by some observers, was considered unnecessary or even harmful.

Responding to this perception, politicians recently started to expand some categories of pension benefits for the first time in many years. Two packages passed in 2014 and 2018 were based on typical 'grand coalition' agreements, where each party got what it wanted for their voters, e.g. mothers (with children born before $1992^{2}$ ) or workers with extremely long careers. Given the current outlook on a pronounced and imminent wave of demographic ageing, further amendments made in order to increase benefits for disabled workers appear to be defendable, as this is clearly a vulnerable group facing enormous difficulties if working longer and saving more are basic requirements for future retirees. However, all this contributes to further increases in pension expenditure in decades to come, when financing the system will become really difficult.

It is currently projected that, in spite of a further decline in the benefit level (by about $10 \%$ by 2045), contribution rates will jump up to $20 \%$ before 2025 and to over $23 \%$ by 2045 under the existing legal framework (Werding, 2019). Together with increasing contribution rates for pub-

2 They are now treated almost as generous as mothers of children born since 1992, with a re-assessment of pensions already awarded. lic health insurance and long-term care, social insurance contributions may even total about $50 \%$ in Germany at this future stage of the ageing process (Werding and Läpple, 2019).

\section{Gaps in the current legal framework}

A new round of reforms is thus definitely needed, adhering to the principles of earlier reforms, extending them to a longer time horizon, and addressing the main gaps involved in the current legal framework. By the simple arithmetic of a pay-as-you-go pension scheme, working longer is the only approach that can produce favourable effects for both the benefit level and the contribution rate. If this approach is ruled out, as it is in current political debates, pensioners are basically doomed to receive very small amounts of annual benefits for a retirement period that becomes longer and longer, while active workers have to pay excessive contribution rates.

Further increasing the legal retirement age after 2030 is thus urgently needed. A related gap that needs to be addressed was created through one of the recent amendments. In 2014, a new option for early retirement was established for workers with 45 years in activity. They can now enter retirement, without any deductions, two years before reaching the age threshold relating to anyone else. It was expected that this would help a minority of loweducated workers in bad health to exit jobs with physically demanding working conditions. Actually, one-third of all new retirees have used this option since 2014, receiving benefits that are substantially higher than those of average pensioners, and most of them are in rather good health (Börsch-Supan et al., 2019). This has, in fact, stopped the increase in the actual, average retirement age - from about 62 years of age in late 1990s to just over 64 years in 2013. For all other workers, early retirement is possible under deductions from their benefits (of $3.6 \%$ per year) that are relatively low by international standards (and the same applies to premiums for working beyond the legal retirement age, of $6 \%$ per year). The rules governing entries into retirement therefore need a comprehensive overhaul.

Another serious gap in the existing framework is that, following the 2001 legislation, supplementary savings for old age are highly recommended and actively subsidised (through direct subsidies for workers on low earnings and a favourable tax treatment for those on higher earnings), but not mandatory. Take-up in this scheme increased significantly in the early years after its introduction, but has come to a halt after 2010 with a coverage of about 10 million people, i.e. about one-third of the target group. The scheme involves a number of additional drawbacks. It is 
mainly targeted at private, third-pillar provisions, which is a high-cost environment in general. Providers have to offer guarantees of the amounts invested, which is also costly. At the same time, the most widely used types of products are mainly invested in bonds, rather than shares, which leads to relatively low returns, certainly under current conditions on financial markets. Also, the market for certified products is perceived to be rather opaque, which makes it difficult for investors to select successful plans and often hinders them from choosing any plan at all. Thus far, all attempts at raising transparency and intensifying competition have not brought much progress in terms of broader coverage.

\section{What is, and what should be, discussed?}

In the run-up to installing the new pension commission, the current government has defined a number of 'stop lines'. There are now official limits with respect to a minimum benefit level and a maximum contribution rate, both valid until 2025, which may become binding shortly before they expire. A kind of unofficial limit is in place regarding the legal retirement age, which the current coalition does not want to discuss during this election period. Also, the government has created the expectation that the commission will continue to define similar - though probably not identical - stop lines for the benefit level and the contribution rate for a longer period of time. This strongly reduces the room for manoeuvre and largely ignores the strength of the ageing process that lies ahead. With an approach of this kind, channelling billions of taxes into the pension budget would be the only way out in the years from 2030 onwards (Werding, 2019), which does not seem to be a feasible solution either.

So far, the public appears to be far more concerned about any further decline in the level of pension benefits than it is with respect to rising contribution rates or taxes. However, if the benefit level were fixed at any rate that sounds adequate, annual amounts of money required to balance the pension budget in the course of the next two decades would most probably create a burden that puts the competitiveness of goods and services produced in Germany at risk and could have a negative impact on economic growth and employment. This could then easily lead to a worst-case scenario. A dynamic development of labour markets that integrates all people of employable age and also continues to attract migrants is an important pre-requisite for steering the German economy and the social protection system of this country through the upcoming period of rapid ageing. To deal with this dilemma, an open discussion about the retirement age and on suitable mechanisms for its future adjustment is simply inevitable.
Furthermore, it needs to be acknowledged that old-age provisions, which are predominantly financed on a payas-you-go basis, are actually not ideal for a country with the demographic situation that Germany will reach after the current transition period, with a level of old-age dependency that will be permanently increased. Yet, a majority of Germans seem to shy away from a higher share of pre-funded old-age provisions, pointing to financialmarket risks and low interest rates as well as the imperfections of the scheme already in place. Therefore, other products and instruments that reduce costs, investment strategies that are suitable in the current low-return environment and alternative institutional arrangements should be discussed.

For instance, given the corporatist traditions of Germany and its welfare state, occupational, second-pillar pensions backed by collective agreements might offer a better platform for expanding coverage in supplementary schemes than third-pillar plans. An amendment of the law on occupational pensions enacted in 2017 already paved the way in this direction. But, with the current uncertainty about future directions for the public pension scheme, nobody has utilised this option so far. Alternatively, investment funds that are somewhere between public and private provisions might prove helpful as a fall-back solution for investors and as a challenge forcing existing providers of financial services to become more competitive.

\section{Promising examples in other European countries}

Considering the increasingly ageing population in Germany, it should ideally be a forerunner among the highly developed countries, demonstrating how to organise - and cushion, to the extent that this is needed - the transition to an economy with an older population. Instead, public discussions in Germany could benefit a lot from taking notice of many examples for promising rules and approaches that have been established in other countries, especially in Europe.

For instance, to deal with their projected ageing processes, Italy (with an enormously long transition period) and Sweden (in a quick move) have first of all fixed the contribution rates for their public, pay-as-you-go pension schemes and installed a strict 'defined contributions' logic to assessing future benefits. Many countries followed the German example in increasing the legal retirement age, reaching the German standard envisaged for 2030 (of 67 years of age) at an earlier stage (in Ireland: 2021; the Netherlands: 2021; and Denmark: 2022) or even exceeding it (in Ireland: with 68 years, starting in 2028). A number of countries (again, Denmark and the Netherlands, plus Estonia and Italy) have now also tied their legal age 
thresholds for receiving full benefits to ongoing changes in life-expectancy through automatic, rule-based links, which is helpful in avoiding repeated political discussions about this difficult topic. Early-retirement deductions from full benefits are closer to actuarial standards in many European countries (especially in Greece, Portugal and Spain, with $6 \%$ per year; in the Slovak Republic and in Switzerland, with 6.5 and $6.8 \%$, respectively). ${ }^{3}$

European countries also provide interesting examples of how to run comprehensive systems of supplementary cover for all their employees and retirees based on capital reserves, in spite of the risks and difficulties involved in this type of old-age provisions. Some countries simply have longer traditions in this area, like the Netherlands (with a very broad-based system of occupational pensions). Others have successfully introduced new systems of this kind in recent years, such as Sweden (with their mandatory Premium Pension scheme established in 2000, where quasi-public providers have a core role as a default option for individual investors) or the United Kingdom (with their new Workplace Pension programme established in 2012, based on an automatic enrolment of all workers, combined with an opt-out clause, offering the National Employment Savings Trust (NEST) as a default option for small firms). Assessing the experiences of these and other countries could help inform the public debate about pros and cons of various elements of reforms which should now be seriously considered in Germany as well.

\section{The timing of reforms is the core question}

Open questions regarding the future of old-age provision in Germany are thus not so much what to do, but relate to the appropriate timing of different moves. Further changes in the retirement age need to be announced in good time, to make sure that individuals - employees and employers - can adjust their plans. More importantly, expanding reserves for funded old-age provisions takes time, and too much time has already elapsed without a stringent framework. It is practically too late for helping those who are already approaching retirement and have not started to engage in supplementary savings during the early 2000s. On the other hand, fixing the benefit level for the next twenty years to support these people will leave younger workers without the resources they will need to save for their own retirement phase. Some compromise is obviously needed to define a viable time path for benefits as well as burdens, sharing the latter among all those who are involved in this delayed transition.

3 Information provided in this paragraph is collected from the EU database MISSOC (2020) and from OECD (2019).

\section{References}

Börsch-Supan, A. (2007), Rational pension reform, MEA Discussion Papers, No. 132-2007.

Börsch-Supan, A., T. Bucher-Koenen, N. Goll and F. Hanemann (2019), Targets missed: Three case studies exploiting the linked SHARE-RV data, MEA Discussion Papers, No. 04-2019.

Deutsche Rentenversicherung (2020), Rentenversicherung in Zeitreihen, https://statistik-rente.de/drv/ (24 February 2020).

European Commission and EU Economic Policy Committee (2017), The 2018 ageing report: Underlying assumptions and projection methodologies, European Economy, Institutional Papers, No. 065.

Kreyenfeld, M. (2001), Employment and Fertility: East Germany in the 1990s, Universität Rostock.

MISSOC (2020), Mutual information system on social protection, https:// www.missoc.org/ (24 February 2020).

OECD (2019), Pensions at a glance 2019: OECD and G20 indicators, OECD.

Statistisches Bundesamt (2019), Bevölkerung im Wandel: Annahmen und Ergebnisse der 14. koordinierten Bevölkerungsvorausberechnung, Statistisches Bundesamt.

Statistisches Bundesamt (2020), Bevölkerung und Erwerbstätigkeit: Eheschließungen, Geborene und Gestorbene 1946-2018, Statistisches Bundesamt.

Werding, M. (2007), Social insurance: How to pay for pensions and health care?, in I. Hamm, H. Seitz and M. Werding (eds.), Demographic Change in Germany: The Economic and Fiscal Consequences, Springer, 89-128.

Werding, M. (2016), One pillar crumbling, the others too short: Old-age provision in Germany, National Institute Economic Review, 237(1), R13R21.

Werding, M. (2019), Wie haltbar sind die Haltelinien? Effekte der Rentenreform 2018, ifo Schnelldienst, No. 2/2019, 21-25.

Werding, M. and B. Läpple (2019), Wie variabel ist der demografische A/terungsprozess? Effekte von Geburten und Zuwanderung - Folgen für die soziale Sicherung, Bertelsmann-Stiftung. 